\title{
MENINGKATKAN KEMAMPUAN MENULIS IKLAN BARIS DAN SIKAP KEMANDIRIAN MENGGUNAKAN MEDIA IKLAN KODEK(KORAN LOMBOK POST) PADA PEMBELAJARAN BERBASIS TEKS KELAS VIII SMPN 1 SELONG TAHUN 2018/2019
}

\author{
Islahuddin \\ SMPN 1 Selong \\ Posel: islahuddin17@gmail.com
}

\begin{abstract}
The purpose of this study was to improve the ability to write classified ads and attitudes of independence by using small advertisement media for class VIII students of SMPN 1 Selong in the learning year 2018/2019. This research is classroom action research (CAR) which consists of 2 cycles. Each cycle consists of 4 stages, namely 1) planning stage, 2) implementation, 3) Observation and reflection. The instrument of this research is in the form of tests and observation guidelines. The success of the action is determined by seeing an increase in the average value of the ability to write classified ads in cycle I to cycle II. The results showed an increase in the average value of writing classified ads in the first cycle of 75 to 81 in the second cycle, the score of the independent attitude 76 in the first cycle, to 88 in the second cycle. These results indicate that the use of codec advertisement media can improve the ability to write classified ads and independence in class VIII SMPN 1 Selong Academic Year 2018/2019.
\end{abstract}

Keywords: writing, classified ads; independence; small advertising.

\begin{abstract}
Abstrak
Tujuan Penelitian ini adalah untuk meningkatkan kemampuan menulis iklan baris dan sikap kemandirian dengan menggunakan media iklan kodek pada siswa kelas VIII SMPN 1 Selong tahun pembelajaran 2018/2019. Penelitian ini adalah penelitian tindakan kelas (PTK) yang terdiri dari 2 siklus. Tiap siklus terdiri dari 4 tahap yaitu 1) tahap perencanaan, 2) pelaksanaan, 3) Observasi dan refleksi. Instrumen penelitian ini adalah berupa tes dan pedoman observasi. Keberhasilan tindakan ditentukan dengan melihat peningkatan nilai rata-rata kemampuan menulis iklan baris pada siklus I ke siklus II. Hasil penelitian menunjukkan terdapat peningkatan nilai rata-rata menulis iklan baris pada siklus I sebesar 75 menjadi 81 pada siklus II, skor sikap mandiri 76 pada siklus I, menjadi 88 pada siklus II. Hasil tersebut menunjukkan penggunaan media iklan kodek dapat meningkatkan kemampuan menulis iklan baris dan sikap kemandirian pada siswa kelas VIII SMPN 1 Selong Tahun Pelajaran 2018/2019.
\end{abstract}

Kata Kunci: menulis; iklan baris; sikap kemandirian; iklan kodek.

\section{PENDAHULUAN}

Menteri pendidikan dan kebudayaan sesuai dengan permen Nomor 160 tahun 2014 menargetkan bahwa pada tahun 2019 semua SMP di seluruh Indonesia 100\% menggunakan kurikulum 2013. Menyikapi harapan tersebut kabupaten Lombok Timur pada awal tahun pembelajaran 2018/2019 menetapkan semua SMP baik negeri maupun swasta di daerah tersebut menggunakan kurikulum 2013.

Hal yang paling lekat dengan nama kurikulum 2013 dari sejak pertama diberlakukan sampai sekarang adalah saintifik learning walaupun pada tahap perkembangan terakhir ini disamping metode saintifik sudah terdapat beberapa metode tambahan sebagai alternatif metode yang lain, seperti inquiry discoveri, problem based learning, project based learning dan pembelajaran pedagogie genre. 
Guru-guru Bahasa Indonesia di sekolah-sekolah yang baru melaksanakan tentu mengalami banyak kendala dalam melaksanakan metode saintifik learnig, termasuk langkah pelaksanaannya yang pertama yaitu mengamati. Tentang apa yang diamati, di mana mengamati, siapa yang mengamati merupakan pertanyaan pertanyaan yang sulit diinplikasikan dalam kegiatan pembelajaran. Tidak heran ada guru yang menyatakan bahwa jika siswa sedang diajak keluar kelas itulah kurikulum 2013, karena sedang melakukan pengamatan.

Menurut Lengkanawati (2009) proses belajar mengajar sangat erat kaiatannya dengan apa, siapa, dimana. apa yang diajar, dalam konteks apa, siapa yang diajar, dan dimana mengajar. Hal ini dijadikan dasar untuk memilih pendekatan, metode, bahan ajar, dan teknik yang digunakan dalam pembelajaran bahasa.

Seorang guru yang menerapkan strategi pembelajarannya hendaknya harus kreatif dalam menerjemahkan kegiatan pengamatan, guru hendaknya mengembangkan objek yang diamati dan proses pengamatan agar dapat menolong siswa mencapai tujuan pembelajarannya. Dalam pengamatan ini hendaknya dapat menolong siswa untuk dapat mencapai tujuan pembelajarannnya.

Pembelajaran Bahasa Indonesia di SMP/MTs Berdasarkan kurikulum 2013 berbasis teks, dalam pembelajaran disajikan berbagai jenis teks baik lisan atau tulisan. Pemahaman terhadap jenis teks, kaidah dan konteks suatu teks ditekankan sehingga memudahkan peserta didik menangkap makna yang terkandung dalam suatu teks maupun menyajikan gagasan dalam bentuk teks yang sesuai sehingga memudahkan orang lain memahami gagasan yang ingin disampaikan ( Mendikbud RI, 2013: iii). Pembelajaran Bahasa Indonesia berdasarkan kurikulum 2013 menekankan pentingnya keseimbangan kompetensi sikap, pengetahuan dan keterampilan, kemampuan berbahasa yang dituntut tersebut dibentuk melalui pembelajaran berkelanjutan.

Dalam pembelajaran berbasis teks pembelajaran bahasa Indonesia biasanya secara bertahap dilakukan hal-hal sebagai berikut: memahami teks, memahami struktur teks, menganalisis unsur kebahasan teks, membandingkan teks yang satu dengan yang lain merevisi teks, dan membuat teks. Dalam membuat teks biasanya siswa mengarang atau menulis teks. Dalam menulis jenis teks tertentu inilah diharapkan siswa mampu menghasilkan jenis teks tertentu dengan ketentuan-ketentuan yang sudah dipelajari sebelumnya.

Tujuan akhir pembelajaran teks ialah menjadikan pembelajar memahami serta mampu menggunakan teks ialah menjadikan pembelajar memahami serta mampu menggunakan teks sesuai dengan tujuan sosial teks-teks yang dipelajarinya. Untuk mencapai kompetensi itu pembelajaran berbasis teks hendaknya diberikan dengan tahapan yang kompleks, mulai dari memberi contoh dan menguraikan struktur serta satuan-satuan kebahasaan yang menjadi penanda keberadaan teks tersebut ( pemodelan) sampai kepada upaya menciptakan kemampuan siswa untuk memproduksi teks yang diajarkan ( Mahsun, 2014 : 112)

Menurut Mafrukhi ( 2018: 32 ) suatu media cetak yang sangat efektif dalam menyampaikan pesan yang pada umumnya berupa penawaran barang dan jasa. Iklan yang berisi pesan berupa imbauan disebut iklan layanan masyarakat. 
Iklan kodek (kecil) adalah kolom dalam harian Lombok post yang berisi sejumlah iklan-iklan baris yang berisi penawaran dan perkenalan barang dan jasa. Kolom iklan kodek dapat dimanfaatkan oleh semua kalangan untuk memeromosikan barang dan jasanya dengan biaya yang murah. Satu penerbitan terdiri atas berpuluh-puluh iklan kodek. Iklan dapat ditemukan setiap hari penerbitan Koran Lombok Post.

Struktur iklan baris sangat mudah dikenali, berupa 1) penawaran barang dan jasa, 2) ciri atau kelebihan barang dan jasa, 3) Alamat barang dan jasa. Sedangkan unsur kebahasaannya berupa, kalimat berita, dan kalimat seru. Berupa opini dan fakta. Ciri-cirinya tersaji dalam kotak persegi rata-rata 4 x $5 \mathrm{~cm}$, berisi singkatan kata, djl. Hub. Hrg ng. Hp. Kntrk dan lainnya.

Dengan media yang murah, mudah didapat serta memiliki ciri, struktur, serta unsur kebahasaan yang sederhana. Guru dapat menggunakannya dalam pembelajaran yang efektif dan menyenangkan untuk membantu siswa memahami, menggunakan dan memproduksi teks sesuai dengan kebutuhan yang bermanfaat dan realistis.

Iklan termasuk jenis teks yang dipelajari oleh siswa di kelas VIII. Dalam pembelajaran iklan siswa dituntut memahami jenis iklan, memahami isi iklan, dapat membandingkan ciri teks iklan dengan teks yang lain seperti slogan dan foster. setelah membandingkannya siswa juga dapat mengidentifikasi isinya. Menyimpulkan isi teks merupakan langkah yang penting setelah mengidentifikasi isi iklan.

Langkah yang penting dilakukan dalam pembelajaran iklan adalah menelaah pola penyajian dan kebahasaan teks iklan. Langkah terakhir yang dilakukan adalah menyajikan gagasan, pesan, dan ajakan dalam bentuk iklan. Dalam langkah inilah siswa dapat membuat /menulis iklan yang berisi gagasan, pesan, dan ajakan sesuai dengan jenis dan karakter iklan yang dibuat.

Peraturan Presiden Nomor 87 Tahun 2017 tentang Penguatan Pendidikan Karakter (PPK) menuntut guru untuk melakukan penguatan karakter siswa yang menginternalisasikan nilai-nilai utama PPK yaitu religius, nasionalis, kemandirian, gotong-royang dan integritas dalam setiap kegaiatan pembelajaran yang dilaksanakan. Selain itu, untuk membangun generasi emas Indonesia, maka perlu dipersiapkan peserta didik yang memiliki keterampilan Abad 21 seperti khususnya keterampilan berpikir kritis dan memecahkan masalah (Critical Thinking and Problem Solving Skills), keterampilan untuk bekerjasama (Collaboration kemampuan untuk berkreativitas (Creativity), dan kemampuan untuk berkomunikasi (Commnication).

Di SMPN 1 Selong khususnya di kelas VIII pembelajaran iklan belum diperlakukan sesuai kurikulum dan paradigma pembelajaran terkini. Siswa diberikan konsep dan contoh iklan secara umum lalu siswa diarahkan untuk menulis iklan. Siswa kurang aktif dan kreatif karena tidak ada pembimbingan, pembelajaran tidak terarah karena tidak umpan balik yang jelas. Produk iklan yang dibuat oleh siswa dinilai berdasarkan aspek yang belum tepat. Media terbatas hanya satu iklan foster yang diambil dari internet atau disuruh membayangkan iklan-iklan niaga berupa baliho yang terpampang di jalan-jalan. Pemahaman secara detail tentang satu jenis iklan sangat diperlukan. Bimbingan dan pendampingan dalam bekerja menulis iklan perlu dilakukan. Adanya sebuah pembelajaran yang dapat memacu kreatifitas dengan pemahaman konsep dan bimbingan yang menyenangkan sangat 
mendesak untuk diterapkan.

Penelitian ini merupakan suatu alternatif dalam mendeskripsikan pembelajaran iklan dengan media yang sederhana, namun menonjolkan pembelajaran saintifik yang berorientasi pada produk dan mengintegrasikan aspek pengetahuan, keterampilan, sikap kemandirian sesuai dengan visi abad 21 membangun generasi emas Indonesia.

\section{METODE PENELITIAN}

Penelitian ini merupakan penelitian tindakan kelas (Classroom Action Research). Penelitian Tindakan Kelas ( PTK) adalah suatu bentuk penelitian yang bersifat reflektif dengan melakukan tindakan tertentu untuk memperbaiki dan meningkatkan kinerja kelas agar lebih berkualitas, sehingga siswa dapat memperoleh hasil belajar yang lebih baik (Asrori, 2008:6). Untuk membuktikan bahwa. Penggunaan Media Iklan kodek pada pembelajaran berbasis teks dapat meningkatkan kemampuan siswa membuat iklan dan meningkatkan sikap kemandirian siswa kelas VIII SMPN 1 Selong Tahun 2018/2019. Penelitian ini diselenggarakan dalam 2 siklus. Masing-masing siklus terdiri atas tahap perencanaan, pelaksanaan tindakan, observasi, evaluasi, dan refleksi di akhir tindakan secara secara sederhana prosedur dapat digambarkan sebagai berikut:

Dari perencanaan sampai refleksi disebut satu siklus, jika diperlukan siklus II, bahkan siklus III. Data yang diperlukan dalam penelitian ini adalah kemampuan siswa untuk membuat iklan baris, yang diukur menggunakan test. Sedangkan untuk mengetahui penggunaan media iklan kodek dan sikap kemandirian peneliti mengobservasi aktivitas dan sikap mandiri pembelajaran siswa dan guru dilakukan dengan menggunakan pedoman observasi kegiatan guru dan siswa.Teknik analisis data yang digunakan dalam penelitian ini adalah teknik analisis statistik deskriptif dengan menganalisis hasil belajar (rata-rata kelas ketuntasan belajar individu dan klasikal, serta analisis aktivitas guru dan sikap mandiri siswa). Analisis ini bertujuan untuk mengetahui kemampuan membuat iklan baris, aktifitas guru dan sikap mandiri siswa setelah data diperoleh pada setiap siklus.

Nilai kemampuan membuat iklan baris diperoleh dengan rumus Nilai $=$ skor yang diperoleh: skor maksimum X 100. Ketuntasan belajar individu tercapai apabila setiap siswa mencapai $\geq 75,00$ dan ketuntasan klasikal tercapai apabila siswa tuntas belajar mencapai $\geq$ $\underline{80 \%}$.

Analisis aktivitas dan sikap mandiri siswa diperoleh dengan melihat nilai yang diperoleh siswa dengan mengkategorikannya berdasarkan tabel berikut :

\begin{tabular}{|l|l|}
\hline NILAI & KATEGORI \\
\hline $\mathrm{N}>75$ & baik \\
\hline $50<\mathrm{N} \leq 75$ & Cukup baik \\
\hline $25<\mathrm{N} \leq 50$ & Kurang \\
\hline $\mathrm{N} \leq 25$ & Tidak baik \\
\hline
\end{tabular}

Skor penggunaan media iklan kodek diperoleh dengan menganalisis hasil pengamatan aktivitas guru dengan lembar observasi, dengan rumus :

Skor $=$ skor prolehan $/$ skor maksimum $\times 100 \%$

Penentuan kategori keberhasilan guru dalam menerapkan berdasarkan tabel berikut :

\begin{tabular}{|l|l|}
\hline Rentang nilai & Kategori \\
\hline
\end{tabular}




\begin{tabular}{|l|l|}
\hline $\mathrm{N}>80$ & Sangat baik \\
\hline $60<\mathrm{N} \leq 80$ & Baik \\
\hline $40<\mathrm{N} \leq 60$ & Cukup baik \\
\hline $20<\mathrm{N} \leq 40$ & Kurang \\
\hline $\mathrm{N}<20$ & Tidak baik \\
\hline
\end{tabular}

\section{HASIL DAN PEMABAHASAN}

\section{Siklus I}

\section{a. Perencanaan Kegiatan}

Pada tahap ini peneliti, mengadakan persiapan awal sebelum melakukan tindakan siklus 1. Persiapan awal yang dilakukan adalah berupa memeriksa dan mengondisikan siswa agar siap melakukan pembelajaran. Kebersihan kelas dan hal-hal yang mendukung seperti ketenangan serta kesiapan mental siswa dalam belajar.

Prangkat tindakan juga harus betul-betul dipersiapkan seperti: 1) RPP, 2) Pedoman Observasi, 3) media berupa iklan kodek dari harian lombok post, 4) sejumlah LK, dan 5) instrument evaluasi.

b. Pelaksanaan tindakan

Dalam tahap ini dilakukan pembelajaran dengan menggunakan RPP yang telah dipersiapkan, kegiatan-kegiatan tersebut sudah mengakomodir, paradigma terbaru pembelajaran kurikulum 2013, yang berciri pokok seperti ada unsur literasi, pembelajaran abad 21, dan unsur penguatan pendidikan karakter, adapun langkah-langkah yang ditempuh sbb. :

1. Kegiatan Pendahuluan

a) guru memberi salam.

b) Guru meminta siswa merapikan kelas.

c) Guru meminta siswa berdoa (Religius)

d) Guru mengecek kehadiran.

e) Guru menempel iklan di papan tulis .

f) Siswa mengamati iklan di papan tulis (Literasi)

g) Guru mengajukan pertanyaan terkait iklan yang sedang dipajang di papan tulis (Brain storming)

h) Guru menyampaikan tujuan pembelajaran

i) Guru menyampaikan cakupan materi dan penilaian

2. Kegiatan Inti

a) Guru membangun kontek dengan sebuah ilustrasi tentang seseorang yang butuh uang kemudian ingin menjual sebuah mobil bekas.

b) Guru membagikan masing-masing kelompok sebuah iklan baris, tiap-tiap kelompok diupayakan mendapat iklan baris yang berbeda satu sama lain.

c) Masing-masing kelompok mengamati iklan baris, tentang struktur iklan baris.

d) Masing-masing kelompok membuat satu bentuk iklan baris baik tentang barang atau jasa berdasarkan iklan baris yang diamati.

e) Masing-masing kelompok mempresentasikan hasil diskusi kelompok.

f) Kelompok yang lain menanggapi kelompok yang presentasi 
g) Guru membahas tentang isi, struktur, dan ciri kebahasaan iklan baris

h) Guru menyimpulkan pelajaran.

i) Guru menekankan nilai-nilai positif seperti kerja sama, kerja keras tanggung jawab yang dikembangkan dalam pembelajaran.

j) Menugaskan siswa untuk mencari iklan baris yang lain dan menyebutkan isi, ciri, struktur dan kebasahaannya.

k) penutup

c. Hasil Evaluasi

Setelah dilakukan pelaksanaan tindakan dan observasi maka diadakan test kemampuan membuat iklan baris. Setelah diadakan penilaian dalam memproduksi teks iklan baris, setelah diperiksa menunjukkan hasil yang belum memuaskan, yaitu dari 32 orang siswa nilai tertinggi dalam pembuatan iklan baris 93 dan skor terendah 60 , dengan rata-rata kelas mencapai 75, Persentase ketuntasan yaitu $78 \%$. Hal ini menunjukkan indikator tindakan belum tercapai.

d. Hasil Observasi

Di bawah ini adalah hasil analisis aktivitas guru pada siklus I

\begin{tabular}{|c|c|c|c|}
\hline SIKLUS & JUMLAH ITEM & JUMLAH SKOR & KATEGORI \\
\hline I & 7 & $27 / 35 \times$ X 100=77 & Cukup \\
\hline
\end{tabular}

Pada siklus I aktivitas guru menunjukkan skor 77, dan berkategori cukup baik.

Di bawah ini adalah hasil analisis sikap mandiri siswa pada siklus I

\begin{tabular}{|l|l|l|l|l|}
\hline SIKLUS & $\begin{array}{l}\text { JUMLAH } \\
\text { SISWA }\end{array}$ & $\begin{array}{l}\text { JUMLAH } \\
\text { ITEM }\end{array}$ & $\begin{array}{l}\text { JUMLAH } \\
\text { SKOR }\end{array}$ & KATEGORI \\
\hline I & 32 & 5 & $19 / 25 \times 100=76$ & Cukup baik \\
\hline
\end{tabular}

Pada tabel di atas sikap mandiri berkategori cukup baik yang ditunjukkan dengan skor 76,

e. Refleksi

Setelah meninjau kegiatan yang dilakukan pada siklus I, dari perencanaan ada beberapa hal yang perlu digarisbawahi untuk menjadi catatan bahkan tindak lanjut dalam pelaksanaan siklus berikutnya. Dalam perencanaan sebelum tindakan kelas, masih terdapat perangkat yang belum dipersiapkan dengan baik, terutama yang menyangkut Instrumen berupa pedoman observasi untuk kegiatan guru. Adanaya siswa yang masih perlu diarahkan karena kebiasaan kecil yaitu keluar kelas jika terjadi pergantian jam. Pada saat pelaksanaan tindakan, terutama waktu diskusi, untuk menganalisis iklan baris, guru harus lebih intensif mengadakan pembimbingan ke tiap kelompok, Yang menarik ketika terjadi pelaporan hasil diskusi, siswa rupanya sudah terbiasa melakukan presentasi. Evaluasi berjalan dengan baik, tidak ada hambatan berjalan dengan lancar.

\section{Siklus II}

a. Perencanaan 
Pada tahap ini peneliti, mengadakan persiapan awal sebelum melakukan tindakan siklus II. Persiapan awal yang dilakukan adalah berupa memeriksa dan mengkondisikan siswa agar siap melakukan pembelajaran. Kebersihan kelas dan hal-hal yang mendukung seperti ketenangan serta kesiapan mental siswa dalam belajar.

b. Pelaksanaan tindakan

Dalam tahap ini dilakukan pembelajaran dengan menggunakan RPP yang telah dipersiapkan, kegiatan-kegiatan tersebut sudah mengakomodir, paradigma terbaru pembelajaran kurikulum 2013, yang berciri pokok seperti ada unsur literasi, pembelajaran abad 21, dan unsur penguatan karakter, adapun langkah-langkah yang ditempuh pada dasrnya sama dengan yang dilakukan pada siklus I hanya saja mendapat perbaikan pada langkah langkah yang kualitas belum baik pada siklus 1, Seperti pengintensifan bimbingan kelompok dan individu ketika menentukan ciri dan kelebihan barang dan jasa, membuat kata-kata singkatan dan membuat alamat yang lengkap.

c. Hasil Evaluasi

Setelah diadakan penilaian dalam memproduksi teks iklan baris, setelah diperiksa menunjukkan hasil yang belum memuaskan, yaitu dari 32 orang siswa nilai tertinggi dalam pembuatan iklan baris 93 dan skor terendah 80, dengan rata-rata kelas mencapai 84. Hal ini sudah menunjukkan indikator tindakan sudah terlampaui.

d. Hasil Observasi

Berikut adalah hasil analisis terhadap aktivitas guru pada siklus II

\begin{tabular}{|l|l|l|l|}
\hline SIKLUS & JUMLAH ITEM & JUMLAH SKOR & KATEGORI \\
\hline II & 7 & $31 / 35$ X 100=89 & baik \\
\hline
\end{tabular}

Adapun hasil analisis terhadap sikap mandiri siswa pada siklus II, sebagai berikut:

\begin{tabular}{|l|l|l|l|l|}
\hline SIKLUS & $\begin{array}{l}\text { JUMLAH } \\
\text { SISWA }\end{array}$ & $\begin{array}{l}\text { JUMLAH } \\
\text { ITEM }\end{array}$ & $\begin{array}{l}\text { JUMLAH } \\
\text { SKOR }\end{array}$ & KATEGORI \\
\hline II & 32 & 5 & $22 / 25 X 100=88$ & baik \\
\hline
\end{tabular}

e. Refleksi

Setelah meninjau kegiatan yang dilakukan pada siklus II, dari perencanaan, pelaksanaan tindakan observasi dan refleksi sudah tidak ada lagi hal-hal prinsip yang berindikasi pada perbaikan langkah-langkah. Malah terdapat beberapa kegiatan yang mengalami perubahan yang sangat baik. Misalnya Siswa lebih cepat menyelesaikan tugas terutama dalam membuat iklan baris, lebih cepat membuat keungulan barang dan jasa serta memilih bentuk alamat yang praktis dan variatif agar relatif cepat untuk menghubungi pemilik jasa dan barang

Berdasarkan hasil analisis data baik hasil tes kemampuan membuat iklan baris dan hasil observasi aktivitas dan sikap mandiri siswa pada siklus I dan II, serta hasil refleksi pada masing-masing siklus, dapat di jelaskan bahwa guru menggunakan media iklan kodek untuk mengajarkan pembuatan iklan baris dapat meningkatkan kemampuan siswa dalam membuat iklan baris, aktivitas dan sikap mandiri belajar siswa pun meningkat bahkan Aktivitas guru juga meningkat. Hal ini berkonstribusi besar dalam meningkatkan kemampuan siswa menganalisis struktur dan unsur kebahasaan iklan kodek yang diambil dari Koran harian Lombok post. 
Aktivitas dan sikap mandiri siswa dalam hal ini tercermin dalam berdiskusi kemudian bertanya dan minta bimbingan guru bagaimana membuat iklan baris baik iklan barang dan jasa berdasarkan contoh, terutama jika mereka ingin atau tertarik mengiklankan suatu produk dan jasa yang dimiliki oleh keluarga dan kerabat terdekat.

Kontribusi dari media yang dipergunakan dalam pembelajaran ini terutama untuk menunjang proses pembelajaran yang dapat meningkatkan kemampuan siswa dalam membuat iklan baris, adalah iklan kodek merupakan iklan yang mudah diperoleh, karena koran Lombok post merupakan koran harian yang sudah memasyarakat di pulau Lombok, rata-rata lembaga pendidikan dan lembaga pemerintah berlangganan koran ini.

Iklan kodek sebagaimana namanya iklan yang berukuran kecil. Ukuran tiap-tiap iklan baris dalam kolom iklan kodek adalah $4 \times 8 \mathrm{~cm}$, sehingga setiap hari dimungkinkan kita dapat memperoleh iklan baris yang relatif banyak. Ketika siswa memanfaatkannya kebutuhan dapat tercukupi bahkan siswa dapat memperoleh iklan baris bervariasi dari segi isi, siswa mendapat pengalaman belajar berbagai jenis, bentuk, isi iklan baris.

Struktur iklan baris yang terdapat dalam iklan kodek sederhana. Jumlah baris kalimat pada tiap tiap iklan berkisar antara 5 s. d. 6 baris. Unsur yang terdapat dalam iklan baris mudah diidentifikasi dan karakternya sederhana seperti nama barang atau jasa, ciri-ciri barang atau jasa, kelebihan atau keistimewaan barang atau jasa, serta alamat pemilik barang atau jasa.

Aktivitas dan sikap mandiri siswa yang tinggi ini, tentu karena distimulus oleh prilaku membimbing, memotivasi, serta tidak bosan-bosannya guru keliling ke masing-masing kelompok untuk mengarahkan siswa secara individual untuk menyelesaikan tugas kelompok dan individu.

Peningkatan yang nyata ini dibuktikan dengan perubahan dari rata-rata kelas pada siklus I sebesar 75 menjadi 84 pada siklus II. Tingkat aktivitas guru dan sikap mandiri siswa yang terus membaik menjadi indikator keberhasilan tindakan ini, pada siklus I aktivitas guru dan sikap mandiri siswa cukup baik, dan pada siklus II sudah pada kategori baik, Sikap mandiri siswa pada siklus I, menunjukkan skor 76 meningkat menjadi 88 pada siklus II.

Dari data kuantitatif tersebut dapat ditegaskan bahwa penggunaan media iklan kodek dapat meningkatkan kemampuan membuat iklan baris dan sikap mandiri siswa kelas VIII SMPN 1 selong tahun pembelajaran 2018/2019. Memang pada siklus I sempat terjadi aktivitas guru dan sikap mandiri siswa yang monoton tidak variatif, tetapi setelah guru mengambil inisiatif dalam meningkatkan pembahasan contoh-contoh yang realistik dari iklan kodek siswa menjadi termotivasi dan bersemangat untuk meningkatkan keingintahuannya untuk mengikuti arahan guru.

Pada siklus II sudah nampak perubahan yang nyata dari aktivitas guru dan sikap mandiri siswa, terlihat yang maju presentasi bukan ketua kelompok saja, tapi sudah menyebar ke anggota kelompok yang lain. Walaupun masih dituntun dalam membuka pembicaraan, tetapi secara umum kemandirian siswa dalam menganalis iklan kodek dan membuat iklan baris sudah meningkat. Melihat kondisi yang demikian, guru pun semakin meningkatkan kegiatan pendampingannya pada anak-anak secara merata, terutama dalam membuat iklan baris barang dan jasa. 
Berdasarkan tindakan yang telah dilakukan bahwa penggunaan iklan kodek untuk meningkatkan kemampuan siswa membuat iklan baris dan sikap mandiri siswa kelas VIII SMPN 1 Selong tahun pembelajaran 2018/2019 dapat dinyatakan mencapai indikator keberhasilan yang telah ditetapkan.

\section{SIMPULAN}

Berdasarkan penelitian tindakan yang dilakukan, dari perencanaan, pelaksanaan, observasi, evaluasi serta refeleksi dapat disimpulkan bahwa 1) terdapat peningkatan kemampuan dan sikap kemamndirian siswa dalam membuat iklan baris dengan menggunakan media iklan kodek pada Koran Lombok post. Hal ini dibuktikan dengan nilai rata-rata membuat iklan baris pada siklus I sebesar 75, meningkat menjadi 84 Pada siklus II. Sikap mandiri terlihat juga meningkat yang dibuktikan dari pengamatan aktivitas dan sikap mandiri siswa pada siklus I 76 meningkat menjadi 88 pada siklus II; 2) penggunaan media iklan kodek pada Koran Lombok post dapat meningkatkan kemampuan menulis iklan baris dan kemandirian; dan 3) media iklan kodek yang diamati oleh siswa, dapat memberikan secara nyata contoh iklan baris baik berupa iklan barang maupun jasa pada siswa. Yang paling penting dalam hal ini siswa dapat mengetahui struktur iklan dan unsur kebahasaannya. Dengan pemodelan iklan baris yang bervariasi sesuai dengan konteks dan kebutuhan masyarakat siswa dapat meniru untuk membuat iklan baris sesuai dengan kebutuhan barang dan jasa yang diiklankan.

\section{DAFTAR PUSTAKA}

Abidin, Yunus. 2016. PembelajaranMultiliterasi: Sebuah Jawaban atas Tantangan Pendidikan Abad ke-21 dalam Konteks Keindonesiaan. Bandung: Refika Aditama.

Ernawati, Kukuh. 2009. Peningkatan Keterampilan menulis Iklan melalui teknik pemodelan pada siswa kelas VII-D SMP Negeri 2 Wanadadi Kabupaten Banjarnegara. Skripsi. Jurusan Bahasa dan Sastra Jawa. Fakultas Bahasa dan Seni. Universitas Negeri Semarang.

Ferdiansyah, Feri. 2011. Upaya meningkatkan kemampuan menulis karangan argumentasi dengan menggunakan media iklan animasi layanan masyarakat. Skripsi. Jurusan PBSI, Fakultas Bahasa dan Seni, UPI Bandung.

Kemendikbud. 2013. Bahasa Indonesia Wahana Pengetahuan. Jakarta : Kemendikbud.

Kemendikbud.2018. Materi Penyegaran Instruktur Kurikulum 2013 Mata Pelajaran Bahasa Indonesia. Jakarta : Kemendikbud.

Kementerian Pendidikan dan Kebudayaan. 2013.Peraturan Menteri Pendidikan dan Kebudayaan Republik Indonesia, No 64 Tahun 2013 tentang "Standar Isi Pendidikan Dasar dan Menengah. Kemendikbud : Jakarta.

Kementerian Pendidikan dan Kebudayaan. 2015.Peraturan Menteri Pendidikan dan Kebudayaan Republik Indonesia, No 23 Tahun 2015 tentang "Gerakan penumbuhan budi pekerti.” Kemendikbud : Jakarta. 
Knap, Laster, 1985. Genre, Teks, Grammar. Sydney: Universitasity of New Southt Wales Press Ltd.

Mafrukhi. 2016. Mahir Berbahasa Indonesia, Jilid 2 Kelas VIII SMP/MTs. Penerbit Erlangga:Jakarta.

Mahsun. 2014. Teks Dalam PembelajaranBahasa Indonesia Kurikulum 2013.PT Raja Grafindo Persada: Jakarta.

Nurhadi, dkk. 2005. Bahasa dan Sastra Indonesia, untuk SMP/MTs Kelas IX.Penerbit Erlangga: Jakarta.

Purwo, Bambang Kaswanti.1993. Pragmatik dan Pengajaran Bahasa: Menyibak kurikulum 1984. Yogjakarta: Kanisius.

Soeharto. 2004. Menyemai Benih-benih Teknologi Pembelajaran. Bandung: Tarsito.

Tarigan, Henry Guntur. 1993. Keterampilan Menulis. Bandung : Angkasa

Tilaar, H.A.R., 1990. Pendidikan dalam Pembangunan Nasional Menyongsong Abad XXI. Jakarta : Balai Pustaka.

Trianto, Agus.2018. Buku Guru Bahasa Indonesia. PT. Mancanan Jaya Cemerlang : Klaten.

Yusuf Hadi, Miarso. 2003. Teknologi Pendidikan. Jakarta: Universitas Negeri Jakarta

Yusuf, Amiruddin. 2011. Peningkatan Keterampilan Menulis Iklan Baris dengan Metode PointCounter-Point melalui Media kartu Identitaspada siswa kelas IXA MTs Nabdlotushshibyan Wonoetinggal Demak Tabun Ajaran 2011/2012, Skripsi. Jurusan Bahasa dan Sastra Indonesia. Fakultas Bahasa dan Seni. Universitas Negeri Semarang.

Zainal, Aqib.2010. Profesionalisme Guru dalam Pembelajaran. Surabaya: Insan Cendekia. 